\title{
Lymphokine-Activated Killer Cell Therapy
}

National Cancer Institute

\section{Source}

National Cancer Institute. Lymphokine-Activated Killer Cell Therapy. NCI Thesaurus. Code C15412.

The use of lymphokine-activated killer cells in the treatment of any disease or disorder. 